\title{
Teachers' Ideas about Multicultural Education in a Changing Society: the case of the Czech Republic
}

\author{
DANA MOREE \\ Faculty of Humanities, Charles University of Prague, Czech Republic \\ CEES KLAASSEN \\ Department of Pedagogy and Educational Sciences, \\ Radboud University, Nijmegen, The Netherlands \\ WIEL VEUGELERS \\ University for Humanistics, Utrecht, The Netherlands
}

\begin{abstract}
This article draws on Czech teachers' ideas about multicultural education at a time when the teaching of multicultural education has become obligatory for primary and secondary schools. After describing the broader context within which this reform has taken place - specifically, the transformation of the educational system and the changing ethnic mosaic of the Czech Republic - the authors present results of a qualitative research study of Czech teachers' ideas about multicultural education.
\end{abstract}

On 24 September 2004 a new School Act was adopted in the Czech Republic, changing both the structure and content of school education. One of the implications of the Act is the introduction of multicultural education (MCE) as an obligatory part of new curricula in primary and secondary schools. The process of education change of which the School Act is a part is undoubtedly very complex with many key players and many factors influencing its results. Teachers have a special significance in this process since 'educational change depends on what teachers do and think' (Fullan, 1982, p. 107). The main aim of this article is to present the results of a qualitative research study on teachers' ideas concerning MCE - in other words to show something of what teachers think. The study presented in this article is part of a larger research programme on social change, education, teachers and the introduction of MCE in the Czech Republic. In this wider research, we have also concentrated on the issue of what teachers actually do.

The article is in four parts. First, we briefly describe the role of teachers with regard to education policy in the changing Czech social and political context. Second, we explore how MCE is understood in the Czech Republic and how this is related to international debates on the issue. Third, we indicate some key features of the multicultural context of the country and the attitudes of the Czech majority towards migrant and minority groups. Fourth, we will present the results of our qualitative study on teachers' ideas about MCE.

\section{Education and Teachers in a Changing Social and Political Context}

Education contributes to the reproduction and transformation of society. On the political level education can be used as a vehicle for changing society or to prepare students to adjust to changing social and political ideas and relations (Goodson, 2005). Changes in society are inevitably linked with changes in education. Schools in the Communist system were well known for their 
subordination to the aim of creating 'a good, socially minded citizen of a socialist society, who would also realize in his private life the values of a classless, egalitarian, and collective society' (Kozakiewicz, 1992, p. 4). To try to achieve these aims curriculum content was controlled and transferred to students by a didactic - i.e. behaviourist oriented - teaching style. Czech teachers very often refer to this as frontal teaching, where the main emphasis is on passing information on to students. In the context of political changes after 1989 the Czech education system differs in some specific respects to other countries of central and eastern Europe. Before 1989 the Communist influence on the school system varied from country to country and in this respect the Czech Republic belonged to the hardliners (Mitter, 2003). The fact that the Czech Republic is the last country in the region implementing the first complex school reform since 1984 (Kozakiewicz, 1992; Koucky, 1996) is in this context relatively surprising.

The implementation of educational change signalled by the new School Act will be influenced by many factors but it is clear that teachers, as important pedagogical agents, will play a crucial role (Fullan, 1982; Hargreaves, 1994). To a certain extent they have to follow formal educational policy since as civil servants they are part of the system. Sometimes, however, they can be actively involved in changing society or creating counter practices in the borders of the system. Hence, teachers implicitly and explicitly shape the formal policy and curriculum. Educational change is always the product of a combination of top-down and bottom-up processes (Veugelers, 2004). Historical periods characterised by more autonomy for schools and teachers, either explicitly 'given' by the political system or the result of inefficient functioning of the system, can empower teachers and give them more possibilities actively to create their own pedagogical practice. The period since 1989 was characterised first by a weakening of structural control of education by the political system, and later by a replacing of the old structures with new ones designed explicitly to enable schools and teachers to be actively and creatively involved in shaping their own pedagogic practice (Tomusk, 2001). Given teachers' potentially pivotal position it is important to do research on their beliefs and practices while also taking into consideration their own life histories and current views on the socio-political context and goals of education (Klaassen, 2002).

In terms of curricular content, the reform brings about two essential changes. In the first place, the results of the teaching and learning process are in future supposed to be not only assessed by the amount of information transmitted (which has been the case up to now), but also by the competencies developed by students. In the second place, the curriculum is defined as having two aspects. The first is comprised of subject knowledge (e.g. language and language communication, mathematics and its application, human beings and society) and the second aspect is made up of socalled cross-curricular topics, including social skills education, awareness of the European and global context, multicultural education, environmental education and media education (Doležalová et al, 2004). Cross-curricula topics are expected to permeate all subjects and areas, reflecting what Anderson et al (2000) describe as the 'infusion model' (see also Faas, 2008).

The implementation of the changes is planned on two levels. The Ministry of Education in cooperation with the Research Institute of Education in Prague [Výzkumný ústav pedagogický v Praze] is preparing guidelines for the reform. Schools will have the freedom (and duty) to handle what is expected of them in their own way. Each school will have to prepare a so-called School Educational Programme, which will contain a specific curriculum based on the general guidelines. The guidelines were produced in developmental stages. The first to be produced were for general grammar schools (gymnázia) educating students from 15 to 19 years of age, followed by the guidelines for primary schools attended by children from 6 to 16 years of age. Guidelines for vocational grammar schools have at the time of writing (August 2007) not been prepared.

Changes in the curriculum and the implementation of the changes mean that schools will have more freedom and greater responsibility for their own programme. The implementation of the reform is obligatory for all schools and will be controlled by the Ministry of Education through the Czech School Inspectorate. The new law reflects the changed relationship between state and school: from a centralised system with a fixed curriculum to more autonomy for schools and teachers and a more constructivist approach to learning. The Czech Republic is therefore following an international trend of increasing school and teacher autonomy (Veugelers, 2004), though, as 
already indicated, compared to Western countries the Czech education system has had to undergo major changes as it has moved from an authoritarian mode of regulation to a more democratic and decentralised one.

\section{Understandings of Multicultural Education in the Czech Republic}

We know from international literature that MCE is a multifaceted concept (Lynch, 1983; Sleeter \& Grant, 1988; Banks \& Banks, 1989; Hernandez, 1989). The concept can be used in very different ways. In particular, the proposed goals and practices associated with it can differ enormously, and it can be linked with many aspects of school environments and classroom life. Acknowledging this diversity in the way in which the concept of MCE is used is very important when considering its interpretation in the context of school reform.

The main aim of this part of the article is to consider the aspects of MCE that are stressed in the recent Czech school reforms and to compare the way in which MCE is interpreted in the Czech Republic to how it is interpreted elsewhere. We use here the results of a content analysis of the official guidelines for general secondary schools (gymnázia) (Doležalová et al, 2004). The interpretation of MCE found within the guidelines is compared with interpretations evident in the international literature. The guidelines are divided into preamble and content sections, a structure we also follow in the analysis.

The introduction of MCE as a cross-curricular topic is set out in the reform guidelines on three pages (Doležalová et al, 2004) and this gives some idea of how MCE is understood. The preamble introduces the background to, and motive for, the implementation of MCE:

MCE plays an important role in a present as well as future society which is based on
multicultural relations, especially for young people who should be prepared for living in a society
where they will meet people from different nations, ethnic groups, races, religions, as well as
people with different lifestyles and value systems. It should support students in understanding
themselves and their own cultural heritage and, at the same time, their integration into a wider
cultural environment while keeping their own cultural identity, and simultaneously respecting
human and civil rights. The school has an informational and educational role in this process.
(Doležalová et al, 2004, p. 72, translated from Czech)

The preamble's main topic is the question 'what is multiculturalism?', echoing a key question in the international literature, where we find several interpretations. The 'cultural standard' model (Lynch, 1983; Trompenaars, 1989; Hofstede, 1991) suggests that members of particular cultures (meaning here, ethnic groups or nationalities) have tendencies towards specific behaviours, value systems and cultural assumptions. This model defines the core purpose of MCE as helping the majority to understand and live with other ethnic groups. In contrast, the 'multiple-identities' or 'transcultural' model (Flechsig, 2000; Banks, 2004) views the individual as a unique human with multiple allegiances to multiple identities. Banks (2004) even talks about the necessity of developing national, regional and global identities. Due to processes of globalisation and increasing interconnectedness there is a tendency to see multiculturalism and also MCE as a broader issue, not necessarily or exclusively linked to ethnicity. The international debate tends to prefer the term 'cultural diversity' or 'pluralism', thus signalling concern with not only ethnicity, but also, for example, with social status, gender or disability (Lynch, 1986; Sleeter \& Grant, 1988; Hernandez, 1989; Bennett, 1990). The international debate in recent years has increasingly tended towards the multiple-identity interpretation based on a dynamic conceptualisation of identity. In other words, it is based on the idea that people have to build many identities during their lives and that identity is something that can be shaped and reshaped (Banks, 2004; see also Gewirtz \& Cribb, 2008).

The preamble of the reform guidelines constructs identity in terms of its static, 'cultural standard' interpretation (it is important to keep one's identity unchanged). The implicit suggestion of the guidelines is, therefore, that there is something like an independent Czech identity, which should be maintained and developed even if 'we' (i.e. the Czech majority) learn how to cope with people coming from other ethnic groups. This conceptualisation might have a deep influence not 
only on MCE and its implementation but also on the potential integration of immigrants and minority groups.

When we go one step further in the reform guidelines, we can see that the aims and objectives of MCE are defined in terms of cognitive, affective and behavioural levels, as is also the case in the international literature. However, there are interesting differences in how these levels are understood in the guidelines and the international literature. The international literature tends not to be very clear about concrete aims relating to the three levels but we can nevertheless find some tendencies. On the cognitive level, we find, for example, an emphasis on critical thinking (Lynch, 1983; Bennett, 1990; Gaine \& Weiner, 2005), knowledge about particular cultural groups (Lynch, 1983; Hernandez, 1989) and cognitive reflection on stereotypes and prejudice (Hernandez, 1989; Boyle-Baise \& Gillette, 1998). On the affective level we find an emphasis on positive selfimage, positive attitudes towards different groups (Lynch, 1983; Banks \& Banks, 1989) and intercultural sensitivity (Hammer et al, 2003). On the behavioural level there is a particular emphasis on fostering equality and academic achievement (Sleeter \& Grant, 1988; Banks \& Banks, 1988; Moses, 1997).

A content analysis of the guidelines shows us that on the cognitive level the school reform particularly stresses the importance of informing students about various ethnic groups (whether defined as 'immigrants', 'refugees' or 'minorities') but lacks any reference to critical thinking ability. On the affective level, the school reform stresses the importance of engendering an emotional climate that supports equality but not in the sense of ethno-relativism, which is recommended by intercultural sensitivity theory (Hammer, 2003). Finally, the behavioural aspect is mainly interpreted in the sense of language skills complemented by social skills improvement, which generally matches ideas in the international literature. One aspect missing on the cognitive level is academic achievement, which is not mentioned in the documents at all.

So we can see that the reform guidelines to some extent reflect the international debate but at the same time they appear to be in transition between possible approaches. Moreover, the articulation of what multiculturalism actually means and what the Czech majority can do about their own identity is very vague and it implicitly covers a fear of losing it. It would be interesting to follow the further development of these ideas as they are enacted in practice in Czech schools.

Before presenting the results of the qualitative research, we should explain our own position on how MCE should be interpreted. Our own perspective on the reform documents and the international literature is that we believe international experiences and suggestions must be sensitively implemented in the Czech context: they cannot simply be transferred wholesale. On the other hand, we would argue that the Czech interpretation seems to be too rigid for a globalised world, so for the purposes of evaluating Czech work in this field, we wish to subscribe to the following conceptualisation of MCE: MCE as a holistic pedagogical approach fostering multiple dynamic identities and preparing students for living in a diverse world.

\section{The Multicultural Mosaic of the Czech Republic}

It seems that the Czech reform documents largely associate MCE with the presence of 'foreigners'. This might be due to the fact that the political changes in Czechoslovakia in 1989 took place in a country that perceived itself as almost ethnically homogeneous, and its new openness first to immigration and then to broader international integration (most obviously by membership of the European Union) have since been very important. This is why we would like to present some basic facts about the country's multicultural composition and survey data about the attitudes of the Czech majority to migrants and minority ethnic groups.

Pre-war Czechoslovakia was a multi-ethnic state with large groups of Germans and Roma (Brandes, 2000). After the War, from 1945 to 1947, three million ethnic Germans were expelled (Brandes, 2000; Glassheim, 2005; Staněk \& von Arburg, 2005). During the Communist period of 1948-89 the ethnic background of people was officially regarded as not significant, though the great exception to this 'official' homogeneity was the Roma community, whose culture was systematically destroyed (see, for example, Charter 77, 1978). Diversity was also significantly 
inhibited by very limited immigration, so that Czechoslovakian citizens had very few opportunities to meet newcomers. The journey from a multicultural towards a monocultural society was seemingly continued in 1993 when post-Communist Czechoslovakia divided into two parts - the Czech Republic and the Slovak Republic (Ulc, 1996).

The Czechoslovak borders were opened after 1990, the consequences of which were, firstly, the arrival of economic migrants and, secondly, the arrival of some refugees (mostly from the former Soviet bloc - Belorussia, Ukraine, and Russia - but also from Vietnam and China). Refugee numbers grew in the first years after 1990 from approximately 1600 in 1990 to 18,000 in 2001 when the numbers started to decrease again, falling to 2000 in 2005 (see official pages of Czech Statistical Office; http://czso.cz/csu/cizinci.nsf/kapitola/ciz_rizeni_azyl). The Czech Republic is often criticised internationally - for example, by the International Helsinki Committee for Human Rights - for the fact that less than $2 \%$ of asylum seekers are accepted. Another significant group of newcomers consists of 'foreigners' asking for permanent residence permits. There are about 300,000 of them, mainly from the Ukraine, the Slovak Republic and Vietnam (see more at http://czso.cz/csu/cizinci.nsf/kapitola/ciz_pocet_cizincu). Although 'foreigners' still only represent approximately $3 \%$ of the Czech population, their integration has been problematic, arguably due especially to administrative obstacles that effectively generate segregation (Gabal, 2004). Aside from newcomers there is still, of course, the relatively significant group of around 300,000 people of the Roma minority, a socially excluded group who are attempting a revival of their almost destroyed culture.

The multicultural mosaic of the present-day Czech Republic appears more complex when we consider the attitudes of the majority towards 'foreigners' and people from different cultural and ethnic groups, as several research studies have shown. Prudkýs (2005) work showed that, while the majority of Czech people regarded their own attitudes towards 'foreigners' as positive (approximately 61\%), a lower percentage expressed tolerance towards people with a different skin colour from their own (approximately 43\%). Some 66\% claimed that 'foreigners' cause an increase in crime and $41 \%$ thought that they took working opportunities from local people. Only $21 \%$ thought positively about 'foreigners' bringing new culture and new ideas; $55.2 \%$ of the respondents stated they would prefer Roma people not to live in the Czech Republic, 52.4\% said the same about Albanians and 55\% said this about Afghans. People from Vietman (49.2\%), Romanians (49\%) and Ukrainians (46\%) followed close behind. Similarly, Gabal (2004) showed that most of the Czech population do not regard 'foreigners' coming to the country as a positive phenomenon: $75 \%$ take a strong assimilationist stance towards 'foreigners', arguing that the more they attempt to assimilate then the more the majority will accept them. The only reason given for accepting 'foreigners' is pragmatic: the need for skilled labour.

Given these negative attitudes, it is not surprising that some elements within the Czech Republic are trying to develop initiatives to improve the effective integration of 'foreigners'. Two practical examples, apart from the educational initiatives discussed in this article, are the state integration programme established by the Ministry of Social Affairs and the offering of services to 'foreigners' and asylum seekers by non-governmental organisations.

\section{Research on the Multicultural Ideas and Practice of Czech Teachers}

MCE is a new approach in the Czech school system. The aim of our research was to identify teachers' prior experiences with MCE as well as their understanding of MCE and the obstacles they face in implementing it. The research sample was drawn from teachers in grammar schools of the general type, so called gymnázia, because although all primary and secondary schools have a duty to implement MCE as a cross-curricular topic, they are also dependent upon the publication of general guidelines by the Research Institute of Education in Prague. At the time this research started the only documents ready were for gymnázia, kindergarten and special schools. In finding a representative sample of such schools we settled upon nine gymnázia in suburban and central areas of Prague, since we needed multicultural schools without unusual or special circumstances (such as 
those in border areas with Germany where historic attitudes persist, or schools with unusually low or high numbers of Roma pupils).

The research was carried out with 30 teachers, 10 males and 20 females. Of the men, three were aged 18-30, four 31-40, two 41-50 and one was over 60 . Of the women, five were aged 18-30, six 31-40 and five 41-50. In terms of subject discipline, the distribution was as follows: thirteen were teachers of civics, six taught foreign languages (English and German), three taught Czech language and literature, three history, three a combination of Czech language and history, one taught geography and one physics. As we can see, there were teachers of different age groups and different disciplines in the sample. This is important for two reasons. First, while MCE is not directly linked to any specific curriculum subject, schools as well as teachers tend to be subject-orientated and we were looking at teachers' openness towards the implementation of MCE across disciplines. Second, the reform process suggests that MCE should be implemented not only across all subjects but also that all teachers should do it, so teachers' age categories are significant.

In all cases the schools were initially contacted by phone and the director or deputy suggested a specific teacher that could be used as a contact person. He or she was usually responsible for Civics in the school. Starting with this contact, other teachers in the same school were contacted by the snowballing method, so that those interviewed were those perceived by their colleagues as people who had something to say about MCE. All interviews took between 35 and 45 minutes and we chose a semi-structured interview format, inspired by research on active learning by Niemi (2002) and the link she made between present experiences with a particular approach (active learning in her case) and ideas about the approach. We also included a question on the obstacles that teachers felt they have to deal with. At the beginning the research aims were explained and it was particularly stressed that there were no clear answers to the questions but that any opinion was valid for research purposes. When teachers wanted to add any information, they were not stopped. Interviews were taped and transcribed and the data were analysed by qualitative categorisation (Maykut \& Morehouse, 1994).

The following interview questions were used, generally in this order:

1. Describe up to three teaching situations in which you experienced being a good 'multicultural teacher'. The purpose of this question was to investigate teachers' experiences in the field of MCE.

2. What is your opinion on multicultural education? The purposes of this question were to find out the teachers' opinions about MCE and their understandings of the term.

3. Are there any obstacles to the use of multicultural education at schools and which do you view to be the main ones? The purpose of this question was to investigate where teachers see obstacles to MCE.

\section{Results}

\section{Teachers' Experiences}

Asking teachers about specific situations when they felt like they were being good multicultural teachers revealed different conceptions of what constituted multicultural teaching. Teachers are basically divided into two categories on this issue. Some teachers perceive a direct link between the experience of multicultural teaching and the actual presence of migrant or minority students in their class. Other teachers understand the term 'multicultural situation' in a wider sense, and do not see it as necessarily implying the actual presence of migrant or minority students. These two groups of teachers can be further subdivided into a number of categories.

Some of the teachers who refer to their experiences with migrant or minority students remember specific situations they have had to deal with. They admit feelings of uncertainty, but sometimes also try to find innovative solutions:

I have a Ukrainian boy in my class who made some trouble, because he could not speak proper Czech and so he disturbed the class and did not learn. He was not very popular among the other students. Once I said to him: 'Eduard, isn't it embarrassing for you that you cannot follow me?' And he replied: 'No, it isn't'. And so I said in Russian: 'We can also talk in Russian; that's no problem for me at all'. He was totally astonished and was not able to answer my question. Then 
he learned everything for the next lesson and got a good mark. His classmates started to accept him after this. They saw that he knew something that they did not know, while Eduard noticed he did not know things which the others already did, and I won much more respect in the class. It was interesting how successful I was in integrating him just making use of my knowledge of Russian.[1] (49 year-old male teacher of Civics)

Where some teachers mention examples of creative solutions, others with experience of migrants or minority students in their classes do not remember any specific culturally related interaction during lessons with them. Such teachers typically said that they do teach 'foreign' students, but 'do not have any problem'. Others recounted making use of the presence of 'foreign' students by introducing their experiences into the class (for example, by asking them to prepare a paper or presentation about their customs). Some teachers, by contrast, said they had never had any 'foreign' students in their class.

A number of teachers mentioned school exchange programmes with other schools from (usually) western European countries as the only multicultural experience. These programmes, which are voluntary for schools, offer students from a foreign school the opportunity of visiting Czech students for a while, and vice versa, with students on both sides usually staying with host families. These programmes represent a kind of cultural exchange and sometimes evoke certain dilemmas:

The way the children are brought up in their families plays a big role. When German children come here, they are used to a free lifestyle - discos, nightlife, etc., and their guest parents do not want to understand this - and why should they? They are the ones who are responsible for the students. In such a situation, tolerance is necessary. The German students should understand that they are abroad and that these things work in a different way here. We have other habits and traditions, so he or she should be able to follow these and not to go to the disco. (40 year-old female teacher of Czech language and literature)

Apart from teachers remembering specific experiences with 'foreign' students, many teachers associate their experience of multicultural teaching with a focus on the substantive topics that they consider important for the field of MCE. For example, some of them try to discuss topics about 'the other' during their lessons. They inform students about living in foreign countries, about the different lifestyles there, and sometimes get students to prepare projects about other countries in small groups. Other teachers mainly concentrate on minority groups living in the Czech Republic, of which the Roma are mentioned relatively often. This approach reflects what Lynch (1983) calls the 'ethnic additive' model of curriculum reform where information about 'the other' is added on to the curriculum.

However, a large group of teachers associate multicultural teaching with situations in which they train students in plural thinking within the common curriculum and in doing so develop students' capacity to see different points of view and facets of reality. This approach resembles what Lynch (1983) calls the 'ethno-national' model where every historical or social event is seen from different perspectives. Such teachers, for example, mention using philosophy, Czech-German topics or discussion on actual social developments for these purposes. Such teachers also tend to use methods such as role-play or discussions with guests, rather than teaching from the front of the class. It is interesting that, while these teachers try to develop in their students one of the most important skills for a multicultural society - critical thinking - and they are able to reflect upon these attempts in the context of MCE, at the same time they show some uncertainty whether this approach 'counts' as MCE.

Teachers also say that they face dilemmas about their own attitude. They feel that multicultural topics are connected to teachers' own attitudes and behaviour. They try to create a positive climate in their lessons, but are uncertain about their ability to react in an appropriate way when facing a multiculturally difficult situation. They also have doubts about their own interpretation of particular topics:

A typical example is the Roma question. Students say that of course they do not mind skin colour and that we do not need to talk about it. I try to explain that the Roma have a different culture and that we can mutually enrich each other, but the discussion usually goes in the direction of 
criminality issues or the misuse of social benefits. (30 year-old male teacher of Czech language and literature)

Dilemmas about attitudes are not only an important topic in relation to MCE, but in relation to integration issues more generally. Integration can be described from many perspectives (Berry, 1997) and its value is also questioned in many European countries (Pels, 2005). Czech teachers seem to need further professional development and reflection about what integration means and where the borders are between broad acceptance of cultural differences and living together in one society. In the interviews these dilemmas were addressed more often by younger teachers.

Most of the respondents were able to identify a number of specific situations which they had experienced as being connected to MCE, only differing in their understanding of how such a situation should be interpreted and whether the presence of foreign students necessarily must be a part of it. While some teachers associate MCE with a situation of concrete interaction between the ethnic Czech majority and 'some foreigners', others associate it more with an attitude of openmindedness or becoming a more cosmopolitan citizen. The latter perceive multicultural teaching to be broader than an intercultural encounter, seeing multicultural teaching situations as those encouraging consideration of plural points of view, critical thinking abilities or language issues.

\section{Teachers' Ideas about MCE}

When asked about their own opinion on MCE, the respondents show substantial uncertainty. Their answers are very short and general and most of the teachers only express a general support for MCE, but are unable to define it. All express the view that 'we' (i.e. the Czech majority) should be tolerant because Czech society is going through a process of diversification and people need to be prepared for a new, culturally more diverse situation and thus also for more 'foreign' students being in Czech schools. Some of the respondents are not sure whether MCE is useful at this time or whether it will only become an effective approach when the number of 'foreign' students increases. For all of the respondents, the key question is whether or not MCE can help 'foreign' students to integrate in Czech society.

Mentioning the presence of 'foreign' students seems to be a typical part of the discussion of multiculturalism not only in the Czech Republic, but also in other countries. In the view of some teachers, the absence of or a low number of 'foreign' students in their classes means that there is no problem and thus no need for MCE (Gaine, 1987). Some literature, however, states that the numbers of 'foreign' students is not the key issue: teachers should simply educate students for living in a multicultural society (Gaine, 1987, 1995; Banks, 2004; Gaine \& Weiner, 2005).

Some teachers admit they are vague about what MCE means and say they would welcome a clear explanation of its content. Other teachers consider it useful, although they do not have a clear notion of the meaning of the term. They give a number of basic definitions of MCE, which are usually linked to tolerance, understanding among nations and reflection upon one's own prejudices. For example:

I understand culture as something that divides people - if they are religious or non-religious, foreigners from a completely different cultural background having a very different way of life. So, MCE might be to split students according to what divides them and then to look for issues, which connect them? (50 year-old female teacher of English language)

Another group of teachers understands MCE as familiarisation with diversity. Providing students with information about people from cultural backgrounds that are different to their own is seen as a necessary part of modern education and the teachers are looking for possible ways of doing this. These teachers stress the normal lives of ordinary people, and rather than trying to give fairly abstract information about other cultures and countries they prefer real examples:

Students are not interested in reading about other cultures, but they do like to hear about other people's life experiences and they react in an interesting way. We invited the ambassador of South Africa to our school who talked about problems of Africa, about Mandela and the fight for independence, and the students were enthusiastic. (49 year-old female teacher of civics) 
Some teachers said that MCE involves paying attention to the representation of a range of perspectives within the topics that are already taught (echoing Lynch's ethno-national approach). Contemporary textbooks and the present curriculum set the topics that must be included into particular lessons, with subjects such as history presented in a very Eurocentric way with little opportunity for teachers to add information to change this. One teacher described it as follows:

When I teach about the Middle Ages, there is nothing about China or India. There is a gap. I can somehow try to remedy this, but still I am focused on one cultural interpretation, European in this case. We do not know anything about China or India. If I didn't want to accept this, I would have to skip other topics. These new topics are not elaborated in present materials so it is difficult to include them. (25 year-old male teacher of history)

The last group of teachers understands MCE as plural thinking. They try to train students in the ability to take critical points of view. These teachers understand MCE as a new philosophy of teaching. Most teachers in this group use common curricular content for the presentation of particular topics in a plural, non-Eurocentric way. From the ideas of these teachers it seems that they do already use some elements of the ethno-national model of MCE, probably more than they think.

As a conclusion, we can say that teachers show basic agreement that MCE might be useful, that because the world has changed, a broader, plural perspective is becoming necessary. The respondents appear ready to accept that motivating students towards tolerance or acceptance of difference is part of a democratic education. However, they lack a clear idea of what MCE exactly is and how they should introduce it into their schools. In particular, the respondents showed significant uncertainty about specific methods, strategies and topics.

\section{Teachers' Perceptions of Obstacles to MCE}

While the respondents described their ideas about MCE in very broad and mostly not very concrete terms, they were very clear about what they expected to be the obstacles to MCE, which they defined on two levels: structural obstacles and their own, personal limitations.

Curricula and time were seen as two important obstructions to MCE. Grammar school teachers are given a very specific curricular framework and structure, since they are expected to prepare students for the examinations they need to pass for admission to university. Since these entrance examinations are in general very 'positivistic' [2], they require memorised data rather than examining the students' 'deeper' knowledge or problem-solving skills. Grammar schools, therefore, mainly concentrate on transmitting information and do not have much time left for other teaching approaches:

Personally, I see the period in secondary school as very important from the perspective of students' personality development. But unfortunately the requirements of universities are as they are. We have to prepare our students perfectly so that they do not have to work hard to prepare themselves individually. It is a question of prestige, as well. The more of your students who are admitted to university studies, the better you are rated as a teacher. It is required by parents, students and the whole system. (45 year-old female teacher of civics)

Teachers apparently find themselves in a situation where they have to struggle with many loyalties. The Ministry of Education pushes them to implement the school reform, which is supposed to enhance the training of skills and students' preparation for life in a democratic multicultural society. At the same time, teachers are under structural pressure to stick to a positivistic approach and just pass on information. As a result, the education system at school level does not significantly differ from what teachers were used to before 1990. The questions now are: what is better for students? Should they be prepared for living in a democratic society or for passing entrance examinations? And who is responsible for such decisions? The school reform does not offer clear answers to such questions.

Another osbstacle teachers have to face when implementing MCE is a lack of good materials. They have to invest much of their leisure time in finding extra information and resources and preparing ways of introducing multicultural approaches into their teaching. Existing materials 
replicate the positivistic tradition of the education system, and they are often biased and do not offer teaching methods or strategies for the learning processes MCE requires. The teachers we interviewed feel that the materials are too positivistic and commented that when they need more critical sources, they have to produce them on their own. Mok \& Reinsch (1996) suggest giving teachers guidelines that would help them to recognise which materials are good and which are weak, from an MCE perspective. The comments from teachers suggest that this kind of support as well as a recognition of their complaints might be helpful.

However, teachers see themselves as the biggest obstacle to MCE for several reasons. The respondents admitted that their knowledge of multicultural issues is often very limited. They were conscious that many things are changing very quickly and it is very difficult to keep up, especially for teachers of the humanities. Furthermore, many of the teachers say they are conservative with regard to teaching methods. They are used to a didactic teaching style and have difficulties imagining other strategies. Some of the respondents comment that they have positive experiences with 'frontal' teaching and do not trust other methods, although they have a feeling that they should. (This preference is not uniquely Czech, as is clear from international literature dealing with transitions in educational systems; see, for example, Toots, 2003.) The respondents' limited willingness to use a variety of teaching strategies is very rooted in their uncertainty about their role, as this example reveals:

Some time ago, I had the idea of founding a school discussion club. Students came up with interesting topics like homosexuality, euthanasia, the President of the USA - leader or marionette? Religion - support or weapon? When I presented the idea to other teachers, their first reaction was - will we be able to manage? One colleague said, 'What are we going to do when students say we should expel all Roma from the country? Do we have enough counter arguments? What do we know about Roma at all? We cannot do this without knowing which direction we want to lead the discussion'. When thinking over his reaction, I thought he might be partly right. We should know upfront how we want to conclude the debate. Since we cannot be experts in all fields, we would need a thorough informational and methodological background. We also need to know if we want students to gain information or if we want them to cultivate their attitudes. It's not easy. (49 year-old male teacher of civics and philosophy)

This example illustrates the teachers' uncertainty concerning their role: should they give clear answers or stimulate students to think for themselves and leave some issues open? This uncertainty can partly be attributed to the fact that the Czech school system before 1990 was only aiming at giving clear answers and did not allow teachers or students to ask any questions. These teachers' uncertainty about their role was closely linked to the issue of authenticity, a feeling that MCE is linked to attitudes and to developing tolerant attitudes in students and that if these did not match the teachers' own convictions, the students would notice:

I am a teacher of Czech language and literature and I have real difficulty in teaching about people who - in my opinion - commit crimes. I can see that there are many things which have changed but they have not changed in their essence. I have read authors who are really good and yet they do not fit into the curriculum any more. We still use the stereotypical literary memory. Why are we not allowed to talk about authors who are much closer to a real human story? (42 year-old female teacher of Czech language and literature)

This teacher talks about authors who were and still are a compulsory part of the official curriculum but represent communist ideology and her dilemma goes very deep. Her experience is that she was a 'megaphone' of the Communist regime; she was not allowed to be authentic in the deep human sense. But this feeling comes up again in the context of MCE for her: she asks the question: on whose behalf does she speak? On behalf of a state doctrine (whatever it is) or on behalf of herself? This dilemma seems to be still alive not only in the Czech Republic, but also in other postCommunist countries (Toots, 2003).

Some respondents call for a deeper interdisciplinary approach. They feel that MCE should permeate the whole curriculum and not only be aimed at a number of selected subjects, but they do not know how to handle this in their schools. However, although interdisciplinarity is mentioned relatively often, most of the respondents do not react positively to the suggestion of 
deeper cooperation with their colleagues during the preparation of MCE. A common response is that they know each other too well (and maybe have known each other for too long) to be able to share all of their ideas and feelings.

Some of the respondents also mention students as an obstacle to MCE, claiming that students are very influenced by prejudices present at home or on television. In addition, some argue that the number of students per class (approximately 30) makes dialogue difficult. Some teachers also mention the lack of 'foreign' students in the classroom in this context. However, in general, the respondents mention their students as an obstacle less frequently than themselves, in some respects seeing their students as more skilled or informed than they are. This could also be a reason why some teachers find it easier not to hold many discussions. This aspect of student-teacher interaction would be another interesting topic for further research, but for the moment we can suggest the possibility that a hidden conflict or anxiety about inter-generational exchange may influence MCE implementation.

We can conclude that the obstacles teachers expect in the implementation of MCE are linked to a deep uncertainty about what to do and how to do it. Many of the obstacles are perceived to lie at a structural level (for example, university entrance requirements and the availability of good materials) and surprisingly, teachers also see themselves as a source of many problems and dilemmas. Teachers experience their relationship to MCE as complex. Their uncertainty about what comprises the essence of MCE might be so deep that they do not see the aspects they are already adopting. They can also be uncertain about their professional identity and the quality of their teaching in general, which may signal a wider problem. Many of the obstacles discussed here reflect the problems teachers face in the process of post-Communist transition. They are confronted with many new requirements from their students, schools, the Ministry of Education and society as a whole. This often results in considerable uncertainty, which has to be taken into account when analysing their views and practices regarding MCE.

\section{Conclusions}

The success of the implementation of MCE will be very influenced by what teachers think about the subject and, as we have seen, they are uncertain about many things. They are uncertain about how to define MCE, about their own professional identity and their professionalism and about what society expects from them.

With regard to teachers' uncertainty about what MCE is, the teachers we interviewed were to some extent in a transition phase between two possible approaches to MCE. Some of them associate the subject directly with the presence of student 'foreigners' in their classes or with activities in the field of youth exchanges. This is more in accordance with the cultural standard theory. Here MCE is designed to help the majority to live with immigrants and minority groups who are culturally different, and to support their integration. Another group of teachers associates MCE more with the general situation in a globalised world. These teachers do not assume that the implementation of MCE depends upon the presence of student 'foreigners' but rather aim to train students in plural thinking, helping them to see issues from different perspectives in a dynamic process of looking for answers. This aligns more to the multiple-identities approach and also to 'transcultural' developments in the international MCE debate. It is worth noting that the tension between these two approaches does not appear in the reform guidelines, which are more orientated towards the cultural standard model. This will doubtless emerge in further research which tendency will prevail? Which of the teachers will prefer which of the conceptualisations? And by which means will they seek to realise them?

With regard to teachers' professional identity and sense of professionalism, teachers see themselves as key players in the implementation of MCE but at the same time they see themselves as the main obstacle. Teachers feel that MCE is very linked to their personal opinions and attitudes. Although teachers do not talk about their own ideological views very much, we know that the attitudes of the majority of the Czech population are not very positive about migrants and minority groups (Gabal, 2005; Prudký, 2005). Teachers feel they have to express their ideas in this social and 
political climate, and are reluctant to do so. Their concern about authenticity may cover some deeper aversion towards minorities. Getting to know more about teachers' attitudes to cultural diversity must be an aim of further research.

The international literature stresses the importance of the school environment and teachers' identification with the school (Hargreaves, 1994) but schools do not feature strongly in our interviews. Sometimes one has the feeling that teachers do not identify strongly with their schools at all: if they mention their working environment they say that they cannot imagine starting some innovations with some colleagues. Students are another part of the school environment and surprisingly the concerns of students do not seem to be a key issue for teachers either. If they do mention students, it is not from an optimistic perspective but rather as part of a discussion about the constraints they experience. Some teachers complain about the negative influence of the media and parents' attitudes on their students, but these concerns are not widely voiced. Most teachers are used to playing the role of a walking encyclopaedia or information slot-machine and this is why they feel uncertain about dealing with topics like globalisation or the war in Iraq in school: they cannot give simple answers. Teachers need to learn how to cope with situations which are complex. Moreover, their concern about their role might be another sign of their overall uncertainty. As Gaine (1987) points out, very often MCE is experienced by teachers as a potentially explosive issue. Its content is not easily transferable in the way that, for example, information technology may be: on the contrary, it involves both teachers' and students' own identities. This feeling of potential explosiveness must be even stronger in the case of Czech teachers, whose main teaching strategy so far has been a didactic one, with little scope for discussion.

Finally, there is uncertainty about what Czech society expects of teachers. In Czech society there is an ambiguity about how migrant and minority groups are perceived and this is reflected in the debate in schools. Moreover, because there are not yet significant numbers of migrants and people from minority ethnic groups in the Czech Republic, teachers do not interact with them very often. Hence many teachers feel that MCE is not directly relevant to their own lives. Yet even teachers open to a broader notion of MCE linked to critical thinking have to cope with structural uncertainties. Teachers' feelings of being ground between two millstones were quite acute at the time of the interviews. On the one hand, the school reform corresponds to these teachers' needs, as they perceive them, because it brings more freedom for them and its focus is more on competences than pure knowledge. From this perspective the school reform might be motivating for them. On the other hand, this motivation seems to be weakened by their feelings of time pressure. They feel that MCE should be linked to a more active teaching and learning style, which they perceive as more time consuming. The perception of a lack of time is very often linked to another structural element, namely, the requirement in gymnázia for success in knowledge-oriented examinations for entering higher education. It is not very realistic to expect rapid fundamental change in the process of teaching and learning. So, here is an educational and political question again: what message is Czech society giving? Should teachers simply pass on knowledge or educate in a fuller sense?

Thus we would argue that teachers, as well as the whole of Czech society, are in a transient situation in more than one respect. In the context of $\mathrm{MCE}$, this transition involves a move between possible MCE models and a move towards the use of a wider range of teaching methods, as well as changing teachers' roles. How will they manage? Which factors will be more significant in the process? How far will the implementation of MCE be successful when it is influenced by teachers' previous experiences (which differ according to the length of time they have been teaching)? All of these questions are worth further researching, especially after September 2007 when, officially, the implementation of MCE started in schools.

\section{Notes}

[1] All Czech students had to learn Russian during the Communist period.

[2] Teachers use the word 'positivistic' to denote a pedagogic emphasis on memorising data instead of encouraging interpretation and deeper understanding. In this article we use the word in the same sense. 


\section{References}

Anderson, S.K., MacPhee, D. \& Govan, D. (2000) Infusion of Multicultural Issues in Curricula: a student perspective, Innovative Higher Education, 25, 37-57. http: / / dx.doi.org/10.1023 / A:1007584318881

Banks, J.A. (2004) Diversity and Citizenship Education: global perspectives. San Francisco: Jossey-Bass.

Banks, J.A. \& Banks, C.A.M. (Eds)(1989) Multicultural Education: issues and perspectives. Boston: Allyn \& Bacon.

Bennett, C.I. (1990) Comprehensive Multicultural Education: theory and practice. 2nd edn. Toronto: Allyn $\&$ Bacon.

Berry, J.W. (1997) Immigration, Acculturation, and Adaptation, Applied Psychology, 46(1), 5-34. http:/ / dx.doi.org/10.1111/j.1464-0597.1997.tb01087.x

Brandes, D. (2000) Der Weg zur Vertreibung 1938-1945. Pläne und Entscheidungen zum 'Transfer' der Deutschen aus der Tschechoslowakei und aus Polen, Munich: R. Oldenbourg.

Boyle-Baise, M. \& Gillette, M. (1998) Multicultural Education from a Pedagogical Perspective: a response to radical critiques, Interchange, 29, 17-32. http:/ / dx.doi.org/10.1023/ A:1007444303156

Czech Statistical Office (2001) Census 2001. Prague.

Doležalová, O. et al (2004) Rámcový vzdèlávaci program pro gymnaziálni vzdèlávání [Frame education programme for secondary schools]. Prague: Výzkumný ústav pedagogický.

Faas, D. (2008) From Foreigner Pedagogy to Intercultural Education: an analysis of the German responses to migration-related diversity and its impact upon schools and students, European Educational Research Journal, 7(1), 108-123. http: / / dx.doi.org/10.2304/ eerj.2008.7.1.108

Flechsig, K-H. (2000) Transkulturelles Lernen. Internet Working Paper. Gottingen: Institut fur interkulturelle Didaktik. http: / / www.gwdg.de/ kflechs/ / iikdiaps2-00.htm

Fullan, M. (1982) The Meaning of Educational Change. New York: Teachers College, Columbia University.

Gabal, I. (2004) Analýza postavení cizinců dlouhodoběžijícich v ČR a návrh optimalizačnich krokü [The analysis of foreigners with long-term permits living in the Czech Republic and the proposal of optimization changes]. Prague: Ministry of Internal Affairs of the Czech Republic.

Gaine, C. (1987) No Problem Here: a practical approach to education and race in white schools. London: Hutchinson.

Gaine, C. (1995) Still No Problem Here. Stoke on Trent: Trentham Books.

Gaine, C. \& Weiner, G. (2005) Kids in Cyberspace: teaching anti-racism using the Internet in Britain, Spain and Sweden. Oxford: Symposium Books.

Gewirtz, S. \& Cribb, A. (2008) Taking Identity Seriously: dilemmas for education policy and practice, European Educational Research Journal, 7(1), 39-49. http:/ / dx.doi.org/10.2304/eerj.2008.7.1.39

Glassheim, E. (2005) Ethnic Cleansing, Communism, and Environmental Devastation in Czechoslovakia's Borderlands, 1945-1989, Journal of Modern History, 78, 65-92.

Goodson, I.F. (2005) Learning, Curriculum and Life Politics. London: Routledge.

Hargreaves, A. (1994) Changing Teachers, Changing Times. London: Cassell.

Hammer, M.R., Bennett, M.J. \& Wiseman, R. (2003) Measuring Intercultural Sensitivity: the intercultural development inventory, International Journal of Intercultural Relations, 27, 421-443. http: / / dx.doi.org/10.1016/S0147-1767(03)00032-4

Hernandez, H. (1989) Multicultural Education: a teacher's guide to content and process. New York: Prentice Hall.

Hofstede, G (1991) Allemaal Andersdenkenden. Amsterdam: Uitgeverij Contact.

Klaassen, C. (2002) Teacher Pedagogical Competence and Sensibility, Teaching and Teacher Education, 18, 151-158. http: / / dx.doi.org/10.1016/S0742-051X(01)00060-9

Koucky, J. (1996) Educational Reforms in Changing Societies: Central Europe in the period of transition, European Journal of Education, 31, 7-24.

Kozakiewicz, M. (1992) The Difficult Road to Educational Pluralism in Central and Eastern Europe, UNESCO Prospects, 22(2), 207-215. http://dx.doi.org/10.1007/BF02195547

Lynch J. (1983) The Multicultural Curriculum. London: Batsford.

Lynch J. (1986) Multicultural Education: principles and practice. London: Routlege \& Kegan Paul.

Maykut, P. \& Morehouse, R. (1994). Beginning Qualitative Research. London: Falmer Press. 
Mitter, W. (2003) A Decade of Transformation: educational policies in Central and Eastern Europe, International Review of Education, 49, 75-96. http: / dx.doi.org/10.1023 / A:1022942629565

Mok, I. \& Reinsch, P. (1996) Kieskleurig. Handeling interkultureel lesmateriaal. Alpen aan den Rijn: Samsom H.D. Tjeenk Willink.

Moses, M.S. (1997) Multicultural Education as Fostering Individual Autonomy, Studies in Philosophy and Education, 16, 373-388. http: / dx.doi.org/10.1023/A:1004957802575

Niemi, H. (2002) Active Learning: a cultural change needed in teacher education and schools, Teaching and Teacher Education, 18, 763-780. http:/ / dx.doi.org/10.1016/S0742-051X(02)00042-2

Pels, D. (2005) Een zwak voor Nederland; Ideeën voor een nieuwe politik. Amsterdam: Anthos.

Prudký L. (2005) Pr̆náležitost k národu, vztahy k jiným národnostem a k cizinciom v České republice. Prague: KVDO.

Sleeter, C.E. \& Grant, C.A. (1988) Making Choices for Multicultural Education. New York: Wiley.

Staněk, T. \& von Arburg, A. (2005) Organizované divoké odsuny? Úloha ústředních orgánů při provádění 'evakuace’ německého obyvatelstva (květen až záři 1945), Soudobé dějiny, 3-4.

Tomusk, V. (2001) Enlightenment and Minority Cultures: Central and East European higher education reform ten years later, Higher Education Policy, 14, 61-73. http:/ / dx.doi.org/10.1016/S0952-8733(00)00014-3

Toots, A. (2003) The Role of Values in Citizenship Education: a comparative study of Estonian- and Russianspeaking schools in Estonia, International Journal of Educational Research, 39, 565-576. http:/ / dx.doi.org/10.1016/j.ijer.2004.07.005

Trompenaars, F. (1989) Riding the Waves of Culture. Boston: Nicholas Brealey.

Ulc, O. (1996) Czechoslovakia's Velvet Divorce, East European Quarterly, September.

Veugelers, W. (2004) Between Control and Autonomy, Journal of Educational Change, 5(2), 141-160.

Veugelers, W. \& Vedder, P. (2003) Values in Teaching, Teachers and Teaching, 9, 377-389. http:/ / dx.doi.org/ 10.1080/1354060032000097262

DANA MOREE is an Assistant Professor in the Faculty of Humanities, Charles University of Prague. She studied social pedagogy and anthropology at Charles University and later undertook $\mathrm{PhD}$ research at the University for Humanistics, Utrecht. Alongside her academic activities she works as a trainer for intercultural groups, especially in Czech-German contexts. Correspondence: Dana Moree, FHS UK, U Krize 8, CZ-150 00 Praha 5, Czech Republic (dana.moree@fhs.cuni.cz).

CEES KLAASSEN is a Senior Researcher and Associate Professor of Educational Sciences at the Department of Pedagogy and Educational Sciences, Radboud University. Nijmegen, the Netherlands. He is a sociologist of education and his research interests include socialization and qualification research, political socialization and citizenship education, the moral assignment of the school, teacher professionalism and educational theory. Correspondence: Cees Klaassen, PO Box 9104, NL-6500 HE Nijmegen, Netherlands (c. klaassen@pwo.ru.nl).

WIEL VEUGELERS is a Professor of Education at the University for Humanistics in Utrecht and a researcher and lecturer at the Graduate School of Teaching and Learning at the University of Amsterdam. He is an educational psychologist and his research interests are moral development and citizenship education, educational change and youth cultures. Correspondence: Wiel Veugelers, University for Humanistics, PO Box 797, NL-3500 AT Utrecht, The Netherlands (w.veugelers@uvh.nl). 